\title{
Competition Policy On Microeconomic Level The Impact On Consumer Welfare
}

\author{
Victor Lașcov \\ Drd., University” Lucian Blaga" Sibiu
}

\begin{abstract}
Most research on the microeconomic assessment of the effects of anti-competitive practices relies on real developments, which follow the intervention of the competition authority, compared with what would have happened in the absence of such an intervention. Such a comparison makes it possible to assess the progress made by the objective of competition policy, because of public intervention.

The main objective of applying competition policy is to protect consumer welfare through sanctioning infringements of competition rules and discouraging future anticompetitive behaviour. Thus, it is possible to maintain equal competitive terms on product markets for the benefit of the final consumer. The paper presents an analysis of the evaluations of the competition policy application and the impact of the competition policy on the final consumer.
\end{abstract}

Keywords: competition policy, anticompetitive practices, consumer welfare

\section{Introduction}

The microeconomic effects of anti-competitive practices materialize in the direct impact on the involved businesses, customers and consumers. The microeconomic indicators that allow us to analyse the economic effects of anti-competitive practices are, in particular, the price, quantity and surplus of the consumer. The microeconomic effects of anti-competitive practices and their combating can be direct and indirect. In a narrow sense, combating anti-competitive practices and controlling economic concentrations is the application of competition policy.

For the microeconomic assessment of competition policy, one can use various qualitative and quantitative methods. Quantitative methods mean the ways that lead to 
a numerical estimate of the progress made towards the objective of competition policy. On the contrary, qualitative methods do not lead to a numerical estimate but reflect the perception of the phenomenon by the respondent. A combination of qualitative and quantitative methods is often welcome to arrive at a more comprehensive assessment of the competition authority's intervention in combating anti-competitive practices.

Among the qualitative methods, one can distinguish surveys, interviews and peer reviews between competition authorities, judicial control of decisions taken by the competition authority. Evaluations based on such qualitative methods often focus on determining whether expectations at the time of competition policy intervention have proved to be true. Evaluations using quantitative methods tend to focus more and establish a causality relationship between public intervention and progress made towards achieving the objectives of competition policy increasing consumer welfare, assimilated with consumer surplus.

\section{Assessing the effectiveness of competition policy enforcement measures}

\subsection{The impact of anti-competitive practices on price}

In the field of combating anti-competitive practices, researches have focused in particular on assessing the effects of the cartel and the levels of imposed fines. Works on the effectiveness of other competition policy measures (vertical agreements and dominant position abuse) have been much more limited. Impact assessments tend to focus only on the observed part of the overall effect of the application of competition policy, as undetected infringements of competition rules (including cartels) and deterrent effects are difficult to measure. However, the literature has made an effort to estimate the detection rate of anti-competitive practices and the magnitude of deterrent effects.

There is a lot of disbelief about the assessment of anti-competitive agreements cases, except for cartel ones, and abuses of a dominant position, due to the complexity of the analytical framework and lack of data, and in the absence of robust analysis there are discussions about competition policy failure.

One way to overcome these analytical challenges is the descriptive analysis of the evolution of the economy with and without a competitive policy. Thus, Baker assesses that American firms were able to operate largely without fear of antitrust laws before the passage of the Sherman Act in 1890 and the 1930s when the law was suspended. Based on this "natural" experiment, Baker describing the behaviour of American firms during these periods concludes that the benefits of effective antitrust law enforcement far outweigh government spending for such enforcement (Baker, 2003).

Researchers Gunster and van Dijk in order to assess the effects of antitrust investigations in the EU (including but not limited to cartel cases) on the company's reputation used the event study method (Gunster, 2011). They consider that an inspection carried out at the company results in a negative shock on the prices of its shares of almost five per cent, a final decision has the effect of two per cent reduction in the share price, and a successful call materializes in a positive effect of up to four per cent. The authors to reputational damage resulting from anti-competitive practices 
attribute three-quarters of the total reduction in the market value of companies, which cannot be justified by fines and legal costs.

Aguzzoni also uses event study techniques to estimate the impact of procedural steps in tracking antitrust policy violations on enterprises' share prices. Although European Commission inspections and infringement decisions appear to have a significant negative effect on share prices, the effects of EU court rulings are not significant. Fines represent less than ten per cent of companies' market value loss, from which the authors deduce that most of the losses are due to the cessation of illegal activities (Aguzzoni, 2013).

The report submitted by Deloitte to the UK competition authority found that the results of the survey calculated the abandoned or significantly changed anti-competitive practices that resulted in a decision of the competition authority (Deloitte, 2007). Thus, for each case of abuse of a dominant position sanctioned by the competition authority, 10 potential infringements were discouraged; for each cartel case, 16 potential infringements were discouraged and for each case of illegal trade agreements, 29 potential infringements were discouraged.

London Economics uses a more direct method to assess the effectiveness of competition law enforcement (London Economics, 2011). Based on a survey of more than 800 companies, as well as several law firms, it reports that for every case of abuse of a dominant position, 12 potential violations are discouraged; for each cartel case, 28 probable infringements are deflated, and for each trade agreement case, 40 potential infringements are discouraged. The study finds that companies comply with competition rules, because of fear of reputational damage and criminal penalties associated with non-compliance, followed closely by possible financial sanctions. However, companies also claim that lack of knowledge of competition law is a significant factor in non-compliance. An SEO study for the Dutch competition authority found that for every revealed cartel, five undetected cases of collusive behaviour are altered or discouraged (EC, 2015).

Thus, it appears that enforcement actions have real consequences for the involved undertakings, far exceeding the direct effects of fines and legal costs. As a result, the deterrent effects of these actions appear to be substantial.

Most quantitative assessments of the impact of cartel counter-decisions start with an estimate of the size of the overcharges (meaning the difference between the collusive price and its competitive counterfactual price) resulting from the cartel (EC, 2013). One expects that the cartel ban will eliminate such overcharges. In addition, it acts as a deterrent to companies considering their involvement in current and future cartels.

The restraint effects often reflect in the established overcharges of prohibited cartels (meaning the product between the magnitudes of the cartel surcharge, the duration of the cartel and the size of the market). However, the company's profit maximization theory seems to indicate that the deterrence depends on the cartel detection rate and the level of fines imposed on them. Also, to decide whether to join a cartel or not, an undertaking may consider the indirect consequences, the loss of the value of the shares because of the public damage to its image. In this regard, the deterrent effect of fines may be more limited if competitors participating in the cartel are also fined (Gunster, 2011). 
Much of the empirical work on the impact of cartel policy enforcement rely on John Connor works, who over the years has built a database of over 2000 overload estimates covering over 500 active cartels at a time in the last three centuries (Connor, 2014). In the database, the median overcharge is $23 \%$, and their average value is almost $50 \%$ of the reference price, the price that would have been observed in the market in the absence of collusion. Connor notes that overcharges have been declining since the end of World War II, as competition law enforcement have become more stringent.

However, for two types of cartels (e.g. bid-rigging and "legal" cartels), there was no significant decrease in average overcharges (Connor, 2008). Connor also notes that the overcharges in cases of illegal and convicted cartels are on average 19\% higher than unpunished legal cartels. The cartel is usually banned and considered illegal, while the legal cartel appears in the case of regulated markets where active cooperation between competitors is allowed, to exclude competitive pressures.

Using a similar but smaller database, Connor and Bolotova found that overcharges tend to increase significantly for lasting international cartels (Connor, 2006) In average, cross-border cartel overcharges are 14 percentage points higher than intern cartels, while the level of overload increases by four percentage points for every five additional years of cartel operation. Connor and Bolotova also believe that cartel overcharges in the EU and North America are lower than in the rest of the world, where the application of competition policy may be less stringent.

Researchers Boyer and Kotchoni observe that the data used in these studies are estimates rather than real observations because the genuine illegal profits of cartels are rarely observable (Boyer, 2011). They claim that a more econometric treatment of the model error, the estimation error and the publication bias would reduce the estimate of the median surcharge to $14 \%$ and the average overcharge at $17.5 \%$ of the reference price. The sudden reduction in average overcharges compared to Connor's research can be partly explained by removing uncertain confidence values from the sample.

In a study conducted for the European Commission, Komninos examines empirical evidence on the effects of cartels on overcharges (EC, 2009). Unlike Connor, this study only considers cartels that began after 1960. It focuses on reported price overruns, scientific research, and peer reviews. Based on a limited sample of 114 cartels, it appears that $93 \%$ of cartels lead to s overcharges, but there is a considerable variation in overcharges caused by cartels.

Professor Smuda explains the magnitude of overcharges in a sample of 191 surcharge estimates from the Connor database, depending on the characteristics of the cartel and the market environment (Smuda, 2012). Its focus on European markets allows it to capture regional variations in Europe. He agrees with Connor and Bolotova that international cartels get significantly higher prices than domestic cartels. Moreover, cartels in Western and Northern Europe (except for the United Kingdom) appear to be less effective in obtaining higher overcharges than cartels based elsewhere on the continent.

However, Smuda finds no significant difference between the overcharges of legal and detected illegal cartels, which is contrary to Connor's finding. The results can be explained by Boshoff's research, which by analysing the evolution of prices in cartel 
cases in South Africa finds the preservation of collusive effects, mainly high prices, after liberalization and the elimination of legal cartels (Boshoff, 2013).

According to current cartel deterrence studies, Smuda adopts the principle that companies will engage in collusive behaviour if the gains from pricing (measured by overcharges on the number of goods sold during the cartel) exceed the expected penalty, which depends on the probability detection and the level of fines applied in that (Smuda, 2012). According to the EU Guidelines on the calculation of fines, their level depends on several factors, including the number of sales related to the infringement and its duration. Calculating with a detection probability of $33 \%$, an average cartel overcharge of $21.9 \%$ and an average duration of 5.7 years, the optimal fine requirement for an average cartel should be $(3 \times 5,7 \times 21.9 \%)=374.49 \%$ of the sales turnover.

Such a fine level cannot be achieved by limiting it to $10 \%$ of the total turnover in the previous business year. In conclusion, Smuda mentions that the incentives of taking part in collusive agreements still seem too great to obtain optimal deterrence. The paper concludes with a number of suggestions to discourage anti-competitive practices, including stronger enforcement of private rights, the introduction of personal liability of those involved in the cartel and payments to informers.

Based on a sample of 64 cartels traced by the EU, Combe and Monnier found that EU fines are below the illicit value gained from cartel membership, a negative fact about their deterrent effects (Combe, 2009). Mariniello confirms that, on average, the fines are well below the damage caused by the discovered cartels. Therefore, most research parts seem to support a stricter application of cartel rules or higher charges (Mariniello, 2013). However, Massimo Motta, former Chief Economist at DG Comp, considers that fines set in line with relevant EU guidelines are not inadequate to discourage.

Contrary to the broad consensus in the literature on the level of fines, the conclusions on the impact of clemency programs on cartel detection do not have the same result. Harrington and Chang, for example, point out that the introduction of a clemency program may increase the detection rate of less stable cartels, but has little effect on stable ones, which are the most harmful cartels (Harrington, 2009). Miller, on the other hand, argues that the introduction of these programs has led to a $40 \%$ reduction in the number of detected cartels (Miller, 2009).

Estimating the probability of cartel detection is very difficult, much less measuring the impact of an outstanding enforcement effort on the detection of the cartel. Connor and Lande cite several studies that report detection probabilities between $10 \%$ and $33 \%$ (Connor, 2012).

Combe estimates the probability of an EU cartel being discovered in a given year at around $13 \%$. Combe also evaluated the efficiency in detecting cartels over time. In particular, the introduction of clemency programs in the European Union in 1996, which helped to increase the probability of detection (Combe, 2008). Thus, after 1996, in eight years, 40 cartels were detected, which corresponds to 5 detections per year in average, while before 1996 - in 28 years - we counted 46 cartels detected, which involves 1, 64 detections per year in average. 
This sharp increase in detected cartels could be explained by the introduction of clemency programs. Indeed, in the first period, if these programs are effective, their introduction should have helped to increase the probability of detection, as these programs reduce the costs of investigations, facilitate investigations and evidence collection and jeopardize the stability of the cartel. In the end, these programs should discourage cartel formation, and therefore we could see a reduction in the number of cartels detected - if fewer cartels form. However, as Motta and Pollo have shown, these programs can also have a counterproductive effect, as reducing expected fines can lead to collusive agreements and promote coordination (Pollo, 1999).

Based on the similarity between trapping wild animals and discovering illegal cartels, Ormosi offers the use of capture-recapture models in his paper, - a method widely used for wildlife population studies in ecology, to study cartel detection, survival and deterrence rates (Ormosi, 2011). Ormosi uses a different methodology and confirms that between 1985 and 2005, less than a fifth of EU cartels were detected. The survival of the cartels - interpreted as future catchability - is about $30 \%$ in the year following the capture. Meaning that during this crucial period, about $70 \%$ of the cartel companies may disappear, decide not to participate in the cartel again, or simply to be a part of the subpopulation that is never captured again, for example, because it becomes more alert. However, for those firms that become captive later, the apparent survival increases to almost 90\%. Finally, the introduction of the $1996 \mathrm{EU}$ clemency program seem to stimulate discouragement.

Analysing the evolution over time of the Finnish industry, Hyytinen finds out that at the end of a period when the cartel in Finland was legal (1951-1990) almost all production industries were cartelized (Hyytinen, 2018). Similarly, Baker provides evidence that periods of more relaxed enforcement of antitrust law in the United States have been followed by an increase in anti-competitive behaviour (Baker, 2003). On the other hand, stricter application (in any form) should contribute to greater deterrence. Miller, for example, finds that the number of cartel discoveries increases around the date of introduction of clemency and then falls below pre-clemency levels (Miller, 2009). He claims that this model is in line with the improved detection and deterrence of the cartel.

Studies have shown that stronger enforcement of the US and EU cartel control policy, in particular, has contributed to the observed drop in excessive prices. There is also considerable variation in average overcharges. However, the use in the question of the appropriate fine levels of the average surcharge rate between $15 \%$ and $20 \%$ would be reasonable $(\mathrm{EC}, 2015)$. In this regard, there may also be an argument for imposing higher fines on more durable and international cartels, as the surcharges are higher in such cartels.

Some papers have tried to address the question of whether the current fines are sufficient to discourage companies from joining cartels. Most of these works retrospectively calculate the net benefits of merging cartels that are known to have existed in the past. Such net benefits depend on many factors, including the level of overcharges, the duration of the cartel, the size of the market, the probability of the cartel being detected by competition authorities and the approximate level of fines 
imposed in the event of detection. The chance of detection is burdensome to determine because cartels that are not detected are indistinct by definition. However, researchers have developed methods to overcome this challenge and have come to the stark conclusion that four out of five cartels remain undetected.

Calculating the net benefits of participating in the cartel remains very difficult. However, the documents using the net benefit approach conclude that the current levels of fines are insufficient to discourage companies from joining the cartel and those they need to increase. Other authors conclude that one can take some other actions to reduce companies' tendency to engage in collusive behaviour, including increasing resources for cartel detection, informers' payments, and promoting a competitive culture (Smuda, 2012).

The impact analysis of the application of competition policy on innovation is particularly relevant. Competition policy can help strengthen incentives for companies to engage in innovative activities. Competition policy decisions should also take into account the impact on the innovative performance of the parties or competitors concerned.

\subsection{Assessment of the injury of competitors}

Anyone who has suffered damage because of an infringement of Articles 101 or 102 of the Treaty on the Functioning of the European Union (TFEU) is eligible to compensation for such damage. The EU Court of Justice has argued that EU primary law (EC, 2006) guarantees this right. Compensation means bringing the injured party into the situation in which it would have occurred if there had been no infringement. Therefore, the compensation includes not only the repair of the damage related to the actual loss suffered (damnum emergens) but also that of the loss of profit (lucrum cessans) and the interest payment. The effective loss means a reduction in a person's assets; the loss of profit means that those assets did not increase, which would have happened if EC regulations had not been violated.

In assessing the damage suffered by competitors, it is necessary to take into account the period and duration of the anti-competitive practice. In case of an anti-competitive practice initiation, the economic effects felt by competitors materialize in increased costs or reduced income, which result in a decrease in the profit of the undertaking concerned. Because of the competitive infringement, the market share of competing enterprises affected by this anti-competitive practice reduces. Because of the anticompetitive actions of the infringing undertaking, the profitability of these undertakings increases. At the same time, this may be lacking in the first stage of the implementation of the foreclosure practice, while the competing undertakings may be forced to leave the market.

If, because of the anti-competitive practice, the infringing company manages to eliminate competitors from the market and prevent the entry of new competitors, it will benefit from overcharges that would allow it to recover the losses incurred in the first stage, accumulating increased profits. Because of eliminating competitors, customers, 
and consumers will have to pay higher prices or purchase lower quality products. At the same time, it is necessary to mention that for the effects of anti-competitive practices to occur, it is not required to exclude the competitor completely. It is crucial that because of the anti-competitive actions, the competition pressure decreases.

The intervention of the competition authority to eliminate competitive practices aims to restore the existing competitive environment before the infringement. The success rate of public intervention depends on the specifics of the affected market and the structural changes that have taken place. In some cases, removing the negative effects of anti-competitive actions can be difficult and long lasting, for example in the case of long-term contracts, network effects, irretrievable costs, and others.

To demonstrate the loss of profit suffered by the competitor of the undertaking, which committed the anti-competitive practice, the method of comparison can be used by analysing the profit made by the affected company during the infringement and the gain, which it would have obtained if the violation did not take place (counterfactual scenario). The difference in the profit of the company concerned is the injury suffered by the company because of anti-competitive practice. In the case of an enterprise existing on the market for a longer time, economic data can be used until the infringement.

If, because of the anti-competitive practice, a new competitor is prevented from entering the market, the actual profit of the undertaking concerned is zero, in which case it is necessary to demonstrate what profit the company would have made in a noninfringing market. In cases where access to the market is forbidden, the excluded person did not make a profit but suffered losses (costs that he did not recover because he could no longer enter the market).

The estimation of the affected enterprise lost profit can be in several ways. Directly, by determining the counterfactual gain from the difference between the counterfactual income and cost, and indirectly, based on the average profit margin per unit of the sold product in the scenario where one supposes that no violation happened, so it multiplies by the number of unsold items because of the infraction. At the same time, depending on the available data, the method chosen to determine the injury caused by the anticompetitive practice should also take into account other factors that could influence the company's profitability. Thus, counterfactual revenues and costs should be adjusted depending on several factors, such as legislative changes, increased cost of production factors unrelated to anti-competitive practice, and others.

In cases where one uses exclusionary practices, market shares can play a crucial role as an indicator in calculating the loss of profit by comparative methods, such as comparison over time. For example, one can use a comparative approach to obtain the approximate market share of an excluded competitor in the absence of the infringement. The profit loss could be quantified by multiplying the observation data on real revenues and costs per unit (or actual average profit margin) by the additional quantities corresponding to a higher counterfactual profit margin, estimated in the absence of the infringement. These results rely on the presumption that unit revenues and costs have not undergone significant changes in the counterfactual scenario and could be accepted 
by the court as an estimate of the damage suffered, possibly as prima facie evidence or as a sufficient argument to change the burden of proof.

A more accurate estimate would assess the evolution of revenues and costs in the scenario, if sufficient data were available. If market share is used as an indicator in estimating the loss of profit, it should be taken into account that it may fluctuate due to factors other than infringement. It is also possible that, if the violation has resulted in a decrease in the total market size, then the income of the excluded competitor, assessed based on actual market shares, will be underestimated (EC, 2013).

Other geographic or product markets may be used to assess the injury caused by the anti-competitive practice based on the comparison method. Undertakings with similar revenues and costs in a different market can serve as a basis for assessing the income and charges of the affected company if the infringement had not occurred. If a competitor of a monopolistic enterprise was harmed, this approach is advantageous.

Considering that the market situation does not immediately return to the state before the infringement, the competing undertaking affected by a competitive practice should also assess the future missed profits, the period considered must be reasonable, taking into account the specificity of the relevant market. The loss of future profits is particularly significant if the excluded competitors can no longer return to the market or regain full market share due to the effects that persist after the infringement has ceased.

In cases where a competitor is also a customer of the infringing undertaking, the exclusionary practices could affect the competitor as far as it purchases from it. In these situations, the injury caused by the infringement is determined based on increased costs, but taking into account the loss of profit due to the lower volume of production or sales, unless the violation had taken place.

It can be seen that, for quantification, competitors affected by an overcharge are in a position similar to that of cartel members' customers, or of an undertaking that commits another type of infringement, leading to an overcharge. It can be transferred to customers or endorsed by the affected company. If the overcharge was transferred to the customers of the concerned company, then its customers were also harmed and may claim compensation for sales volumes lost because of the price increase.

\section{Assessing the impact of competition policy on consumer welfare}

The calculation of the impact on consumer welfare is made by using direct or indirect assessment methods, depending on the information available.

The OECD Report on the Analysis of the Impact of Regulations on the Competitive Environment in Romania presents the direct method of assessing the impact on consumer welfare. The effects of anti-competitive practices are usually examined as the equilibrium point shift on the demand curve. For anti-competitive actions that have the effect of limiting supply or increasing prices, consumer injury is estimated by assessing the change in consumer surplus (OECD, 2016).

Changes in consumer surplus in the graph in Fig. 1 illustrates a constant curve of demand elasticity. Competitive equilibrium is different from restrictive balance from two essential points of view: lower price and higher quantity. 


\section{$4^{\text {th }}$ International Conference on BUSINESS, MANAGEMENT \& ECONOMICS}

15 - 17 DECEMBER 2020

BERLIN, GERMANY

Figure.1 Changes in consumer surplus

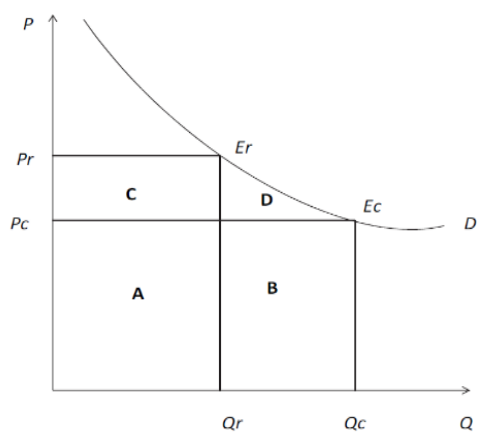

Source: (OECD, 2014)

Where:

Er - restrictive balance indicates the balance in the context of distortion or restriction of competition as a result of anti-competitive practice;

Ec - competitive equilibrium indicates the equilibrium point in case of effective competition;

Pr - the equilibrium price established because of the restriction of competition;

Pc - the equilibrium price established in the case of effective competition;

Qr - the equilibrium quantity traded as a result of the restriction of competition;

Qc - the equilibrium quantity traded in the case of effective competition.

Starting from the presumption of a constant demand elasticity, the impact on consumer welfare (ICW) in Fig. 1 is calculated according to the formula:

$$
I C W=C+D \approx\left(P_{r}-P_{c}\right) Q_{r}+\frac{1}{2}\left(P_{r}-P_{c}\right)\left(Q_{c}-Q_{r}\right)
$$

If price changes are expected, a standard form of impact on consumer welfare as a result of the elimination of distortions of competition, the impact on consumers is calculated according to the formula:

$$
I C W=\left(\Delta p \%+\frac{1}{2} E c p \Delta p \%^{2}\right) C A_{r}
$$

Where:

$\Delta p \%$ - the percentage change in price as a result of the restriction of competition, the reference price $\left(p_{c}\right)$ may be used as the price existing before the restriction of competition, the forecast price in the absence of restriction of competition or the price in geographic markets where the competition mechanism is not distorted;

$\boldsymbol{E} \boldsymbol{c} \boldsymbol{p}$ - price elasticity of demand, which determines by the formula:

$$
E_{c p}=\frac{\Delta Q \%}{\Delta p \%}=\frac{\frac{\Delta Q}{Q_{c}}}{\underline{\Delta p}}=\frac{\Delta Q}{\Delta p} \cdot \frac{p_{c}}{Q_{c}}
$$

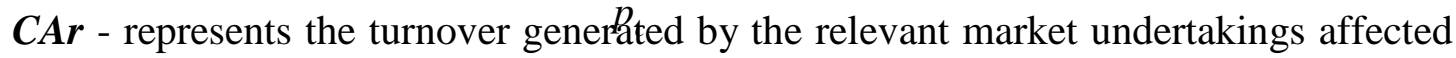
during the period of restriction of competition. 
If the demand elasticity indicator is not known, but is assumed to correspond to a more elastic demand than in the case of a monopoly market, but up to the elasticity indicator characteristic of a perfectly competitive market, the impact on consumer welfare is calculated, taking into account $|E c p|=2$, according to the formula:

$$
I B C=\left(\Delta p \%+\Delta p \%^{2}\right) C A_{r}
$$

The impact of anti-competitive practices on consumer welfare according to the indirect calculation method is assessed depending on the type of infringement, the market affected, the duration and the value of the impact, according to the formula:

$$
I B C=\begin{gathered}
\text { Calculation } \\
\text { basis }
\end{gathered} \quad X \quad \begin{gathered}
\text { Impact } \\
\text { value }
\end{gathered} \quad X \quad \text { Duration }
$$

Where:

Basis of calculation - the turnover of the enterprises involved. Regarding the affected business area, cartel cases and abuse of dominance use the turnover of the cartel members or of the undertaking (s) abusing their dominant position, while for the examination of concentrations a higher definition is used, including the turnover of all firms in the relevant market (OECD, 2013).

Impact value - the turnover percentage of the undertakings operating in the relevant market affected by the practice or action/ inaction leading to the limitation, elimination or distortion of competition;

Duration - is determined depending on the period of the infringement that leads to the limitation, elimination or distortion of competition.

Figure 2. Assumptions suggested by the OECD if information is not available

\begin{tabular}{|l|l|l|l|}
\hline & \multicolumn{1}{|c|}{ Cartel } & $\begin{array}{l}\text { Abuse of a dominant } \\
\text { position }\end{array}$ & \multicolumn{1}{|c|}{$\begin{array}{c}\text { Economic } \\
\text { concentrations }\end{array}$} \\
\hline The calculation basis & $\begin{array}{l}\text { Turnover of the } \\
\text { companies involved }\end{array}$ & $\begin{array}{l}\text { Turnover of the } \\
\text { companies involved }\end{array}$ & $\begin{array}{l}\text { Turnover on the } \\
\text { relevant market }\end{array}$ \\
\hline The impact value & Overcharge 10\% & Overcharge 5\% & Overcharge 3\% \\
\hline Duration & 3 years & 3 years & 2 years \\
\hline
\end{tabular}

Source: (OECD, 2014)

The assumptions that the OECD recommends to use are quite conservative. Mudde and Davies assessed these hypotheses. Mudde, using the cartel life detected by DG Competition, found that the average cartel life is eight years and therefore considers that the one-year price increase assumption could be too conservative (Muddle, 2012). For Davies, DG Competition's case-dependent approach is quite convincing, given that various factors are determining the duration of the cartel, such as the severity of fines and clemency programs, the type of industry and barriers to entry, or other market conditions (OECD, 2013). However, this approach is difficult if not enough information is available, Davies recommends using a single number, somewhere between 1 and 6 years. Regarding the cartel overload, the empirical evidence from the 
scientific literature suggests that the median cartel overcharge is between 17 and 30\%, which makes the $10 \%$ assumption conservative (Connor, 2006).

Given the uncertainties about these assumptions, the OECD also recommends a sensitivity analysis and a range of estimates. Finally, when publishing these estimates, it would be useful to include a clear explanation of the methodology used.

Between 2008 and 2013, the average annual savings of consumers resulting from the interventions of the competition authorities vary between $0.610-2 \%$ of GDP for the US FTC and 6.9 10-2 \% of GDP for the European Commission. These differences in customer savings are because the sizes of the markets in which the CA intervenes, the scope and the number of cases can vary significantly from year to year and in jurisdictions. Another reason for these differences in size is that the assumptions and methodologies used for estimates of customer savings vary from one jurisdiction to another, cumbering comparison of the results of different authorities and why the OECD has made proposals for harmonization of the assumptions used by competition authority. For example, differences can be in terms of price effect, duration and size of the affected market.

A strong point of this approach is that consumer economies are bottom-up estimates closely linked to the decisions taken by competition authorities. However, its main disadvantage is that consumer savings only measure the direct effects on consumer intervention prices. Therefore, these estimates are minuscule, expressed as a percentage of GDP. However, the total benefits extend beyond terms and include effects on quality, choice and innovation. Consumer savings estimates also ignore the indirect consequences of lowering prices on the economy as a whole and the deterrent effects of competition policy, which can be very significant (EC, 2015).

For these reasons, not all competition authorities calculate the savings of consumers resulting from their interventions. Some expressed concern that these estimates oversimplify issues, giving external stakeholders a partial or distorted view of the value and purpose of competition law enforcement. It would argue in favour of using macroeconomic modelling to obtain an estimate of the effects of price reductions for the whole economy.

Based on the analysis of the used methods by different competition authorities, the OECD has made several proposals of uniting the principles and assumptions in the calculation and reporting of consumer savings. The OECD Competition Committee has approved the following fundamentals (OECD, 2014):

1. Use case-specific information, if possible.

2. It is assumed that the lack of intervention will have a negative impact.

3. Static consumer benefits are estimated and, where possible, dynamic benefits are included.

4. The competition authorities shall calculate and publish the estimates on a regular basis.

5. The results are presented as an annual figure and as a dynamic average over 3 years.

6. The results are presented according to the type of anti-competitive practices. 
To justify public spending on competition policies, ones use consumer saving calculations, as they show excellent performance of $\mathrm{CA}$, measured by the cost-benefit ratio. For example, the UK competition authority targets a 10: 1 cost-benefit proportion and uses consumer savings to assess the direct benefits of its interventions. Nevertheless, the self-assessment of competition authorities based on direct consumer savings resulting from counteracting anti-competitive practices creates a risk of excess of zeal due to the authorities' incentive to achieve large figures.

This may lead competition authorities to block too many economic concentrations. Moreover, the over-reliance on such estimates could distort decisions on the allocation of resources within a competition authority. This may lead competition authorities to disregard competitive infringements in low-value markets, where enforcement would be important due to the effects of indirect deterrence. However, such indirect effects are more difficult to measure.

\section{Conclusions}

The impact of competition policy on consumer welfare measures the direct benefits of eliminating anti-competitive practices for consumers (addressing consumer economies). Data collected by competition authorities in investigations offers information to calculate consumer savings resulting from competition policy interventions, including in particular decisions on anti-competitive practices. Consumer savings calculations uses to promote competition, for example, to justify public spending on competition policies. The assessment of the impact on consumer welfare through the direct calculation method depends on the type of market, based on simulations of economic processes. Most competition authorities measure consumer savings based on the indirect way by the estimated reduction in prices resulting from the application of competition policy to the market in question multiplied by the estimated duration of the price reduction.

The decisions of the competition authority may have an effect on the functioning of the market as a whole. A decision may affect not only the parties directly but also other market participants. At the same time, it is necessary to take into account the synergistic effect of multiple decisions in a single sector or market.

\section{References}

- Aguzzoni, Luca, Gregor Langus and Massimo Motta, "The effect of the EU antitrust investigations and fines on a firm's valuation", Journal of Industrial Economics, Vol. 61(2), pp. 290-338. https://www.jstor.org/stable/pdf/43305471.pdf?seq=1

- Baker, Jonathan (2003), "The case of antitrust enforcement", Journal of Economic perspectives, Vol. 17(4), pp. 27-50. Disponibil pe: https://pubs.aeaweb.org/doi/pdf/10.1257/089533003772034880

- Boshoff, Willem H., Illegal Cartel Overcharges in Markets with a Legal Cartel History: The South African Bitumen Market (2013). CCRED Working Paper No. 3/2013, Available

at SSRN: https://papers.ssrn.com/sol3/papers.cfm?abstract_id=2728239Boyer Marcel, 
Kotchoni Rachidi. The Econometrics of Cartel Overcharges. 2011. ffhal-00631429f Disponibil pe: https://hal.archives-ouvertes.fr/hal-00631429/document

- Connor, John M., "Price-fixing overcharges: Revised 3rd Edition", American Antitrust Institute (AAI), $\quad$ February 2014. https://www.researchgate.net/publication/272302307_PriceFixing_Overcharges_Revised_3rd_Edition

- Connor, John M. and Robert H. Lande, "Cartel overcharges and optimal cartel fines', Chapter 88, pp. 2203-2218, in S.W. Waller (ed), Issues in Competition Law and Policy, Vol. 3. (2008), ABA Section of Antitrust Law. https://www.researchgate.net/publication/228198436_Cartel_Overcharges_and_Opti mal_Cartel_Fines

- Connor, John M., Yuliya Bolotova, "Cartel overcharges: Survey and meta-analysis", International Journal of Industrial Organization, Vol. 24 (2006), pp. 1109-1137. https://www.researchgate.net/publication/222521532_Cartel_Overcharges_Survey_an d_Meta-Analysis

- Combe, Emmanuel and Constance Monnier (2009), "Les amendes contre les cartels: La Commission européenne en fait-elle trop?", Concurrences, Vol. 4, pp. 41-50. http://emmanuelcombe.fr/wp-content/uploads/2017/09/trop2009.pdf

- Connor, John M. and Robert H. Lande (2012), "Cartels as rational business strategy: Crime pays", Cardozo Law Review, Vol. 34(427), pp. 427-490 https://www.researchgate.net/publication/228212220_Cartels_As_Rational_Business Strategy_Crime_Pays

- Combe, Emmanuel and Monnier, Constance and Legal, Renaud (2008) Cartels: the Probability of Getting Caught in the European Union. Bruges European Economic Research (BEER) Papers 12/March 2008. (Policy Paper) http://aei.pitt.edu/58577/1/beer15_(13).pdf

- Cauza Courage, C 453/99, Rec., 2001, p. I-6297, punctul 26; cauzele conexate Manfredi, C 295/04 -C-298/04, Rec., 2006, p. I-6619, punctul 60; cauza C-360/09 Pfleiderer, Rep. 2011, p. I-5161, punctul 36; Cauza C-360/09 Pfleiderer, Rep.2011, p. I-5161, punctul 36.

- Cauzele conexate Manfredi, C 295/04 - C-298/04, Rec., 2006, p. I-6619, punctul 95.

- Concluziile avocatului general Capotorti în cauza Ireks-Arkady GmbH/Consiliul și Comisia, 238/78, Rec., 1979, p. 2955, punctul 9.

- Document de lucru al serviciilor Comisiei. Ghid practic cuantificarea prejudiciului în acțiunile în despăgubire întemeiate pe încălcări ale articolului 101 sau 102 din TFUE.

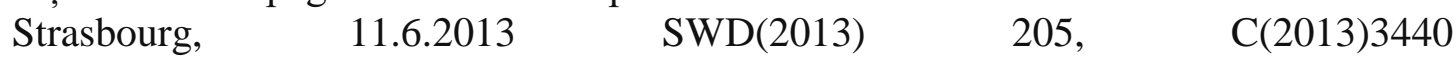
https://ec.europa.eu/competition/antitrust/actionsdamages/quantification_guide_en.pd $\underline{\mathrm{f}}$

- Documentul de lucru al serviciilor Comisiei - Ghid practic privind cuantificarea prejudiciilor în acțiunile în despăgubire întemeiate pe încălcarea articolului 101 sau 102 din Tratatul privind funcționarea Uniunii Europene, 11.6.2013, SWD(2013) 205. https://ec.europa.eu/competition/antitrust/actionsdamages/quantification_guide_ro.pdf

- Deloitte, "The deterrent effect of competition enforcement by the OFT", Report prepared for the Office of Fair Trading, London, 2007. 
https://webarchive.nationalarchives.gov.uk/20140402181127/http://www.oft.gov.uk/s hared_oft/reports/Evaluating-OFTs-work/oft962.pdf

- European Commission. Quantifying antitrust damages. Towards non-binding guidance for courts Study prepared for the European Commission December 2009 ISBN 978-9279-14685-5

(pdf)

https://ec.europa.eu/competition/antitrust/actionsdamages/quantification_study.pdf

- Ex-post economic evaluation of competition policy enforcement: A review of the literature. Report number: ISBN 978-92-79-48350-9, Affiliation: European Commission, Directorate-General for Competition, 2015, - p.73 https://ec.europa.eu/competition/publications/reports/expost_evaluation_competition_ policy_en.pdf

- Gunster, Andrea and Mathijs A. van Dijk (2011), "The impact of European antitrust policy: Evidence from the stock market", International Review of Law and Economics Volume 46, June 2016, Pages 20-33 Disponibil pe: https://www.sciencedirect.com/science/article/abs/pii/S0144818815000721?via\%3Di $\underline{\text { hub }}$

- Harrington, J. E., \& Chang, M. (2009). Modeling the Birth and Death of Cartels with an Application to Evaluating Competition Policy. Journal of the European Economic Association, 7 (6), 1400-1435. http://dx.doi.org/10.1162/JEEA.2009.7.6.1400

- Hyytinen, Ari, Frode Steen, and Otto Toivanen. 2018. "Cartels Uncovered." American Economic Journal: $\quad$ Microeconomics, $10 \quad$ (4): $190-222$. https://www.aeaweb.org/articles?id=10.1257/mic.20160326

- London Economics, "The impact of competition interventions on compliance and deterrence", OFT Report No. 1391, December, 2011 https://webarchive.nationalarchives.gov.uk/20140402165036/http://oft.gov.uk/shared _oft/reports/Evaluating-OFTs-work/oft1391.pdf

- Mariniello, Mario (2013), "Do European Union fines deter price fixing?", Bruegel Policy Brief No. 4, May. https://www.bruegel.org/wpcontent/uploads/imported/publications/Do_European_Union_fines_deter_pricefixing__English_.pdf

- Motta, Massimo (2008), "On cartel deterrence and fines in the European Union", European Competition Law Review, Vol. 29, pp. 209-220.

- Miller, Nathan H. (2009), "Strategic leniency and cartel enforcement", American Economic Review, Vol. 99(3), pp. 750-768. https://www.researchgate.net/publication/227363081_Strategic_Leniency_and_Cartel Enforcement

- Mudde, Jan M. (2012), "The outcome effect of European competition policy for the Netherlands", Master Thesis under the supervision of Prof. Dr. J. van Sinderen. https://www.semanticscholar.org/paper/The-Outcome-Effect-of-EuropeanCompetition-Policy-Mudde/ad69a19945f170f0e70a2d53482f7348fcf952f6

- Orientări privind calcularea amenzilor aplicate în temeiul articolului 23 alineatul (2) litera (a) din Regulamentul (CE) nr. 1/2003 (2006/C 210/02)Text cu relevanţă pentru SEE. JO C 210, 1.9.2006, p. 2-5 


\section{$4^{\text {th }}$ International Conference on BUSINESS, MANAGEMENT \& ECONOMICS}

- Ormosi Peter L., A tip of the iceberg? The probability of catching cartels. CCP Working Paper 11-6 http://competitionpolicy.ac.uk/publications/working-papers

- OECD (2016), OECD Competition Assessment Reviews: Romania, OECD Publishing, Paris. ISBN 978-92-64-25745-9 p.308 http://dx.doi.org/10.1787/9789264257450-en

- OECD, "Assessment of the impact of competition authorities' activities - Note by Prof. Stephen

Davies",

$\mathrm{DAF} / \mathrm{COMP} / \mathrm{WP} 2$

(2013)1. http://www.oecd.org/officialdocuments/publicdisplaydocumentpdf/?cote=DAF/COM $\underline{\text { P/WP2(2013)1\&docLanguage }=E n}$

- OECD, "Guide on impact assessment", DAF/COMP (2014)8. https://www.oecd.org/daf/competition/Guide-competition-impact-assessmentEN.pdf

- Polo, Michele and Motta, Massimo, Leniency Programs and Cartel Prosecution (May 1999). IGIER Working Paper No. 150, Available at SSRN: https://papers.ssrn.com/sol3/papers.cfm?abstract_id=165688

- Smuda Florian, Cartel Overcharges and the Deterrent Effect of EU Competition Law. Discussion Paper No. 12-050 http://ftp.zew.de/pub/zew-docs/dp/dp12050.pdf 